\section{ПРОБЛЕМЫ УПРАВЛЕНЧЕСКОЙ ДЕЯТЕЛЬНОСТИ ОФИЦЕРА И ФОРМИРОВАНИЕ ОРГАНИЗАЦИОННО-УПРАВЛЕНЧЕСКОЙ КОМПЕТЕНТНОСТИ В ВОЕННОМ ВУЗЕ

\author{
С.Г. Марковчин, С.А. Кравцов
}

Марковчин Сергей Григорьевич, кандидат технических наук, начальник, Новосибирское высшее военное командное училище, Новосибирск, Россия. E-mail:nvvku@mil.ru

\author{
Кравцов Сергей Александрович, \\ преподаватель кафедры управления подразделениями \\ в мирное время, Новосибирское высшее военное \\ командное училище, Новосибирск, Россия. \\ SPIN-код: 9862-1727 \\ E-mail: kravtsov.79@mail.ru
}

\begin{abstract}
Аннотация. $B$ статье рассмотрень содержание, роль и история развития управления в деятельности офицеров русской, советской и современной российской армии. Отмечается особая роль педагогической науки в формировании теоретических основ и навыков управленческой деятельности. Авторами были подвергнуть тщзательному анализу, систематизачии, сравнению, сопоставлению и обобщению многие исторические факторы и аспекты в развитии российской армии, касающиеся вопросов управленческой деятельности офицера, что позволило определить подходьл $\kappa$ решению проблемы формирования организационно-управленческой компетентности в военном вузе современной России. Анализируются задачи формирования компетенций в организационно-управленческой деятельности выпускников военных вузов, определенных федеральным государственным образовательным стандартом по специальности «Управление персоналом», определяется сущность управления и организащии, применительно $к$ военной организации. Дается определение сущзости организационно-управленческой компетентности офицера, определяется ее структура и содержимое. Анализируются отличительныле черты процесса формирования организационно-управленческой компетенции в военном вузе. Отмечается, что основой ее формирования служат обучение, воспитание и развитие курсантов в военно-педагогическом прочессе. Проведенное исследование позволило дать определение содержанию организационно-управленческой компетентности офицера Вооруженных Сил Российской Федерации, раскрыть его сущность и структуру; вылвить и обосновать положение, касающегося того, что важнейшим этапом формирования организационноуправленческой компетентности офицера является этап его обучения в военном вузе.
\end{abstract}


Ключевые слова: управленческая деятельность, формирование организационноуправленческой компетентности курсантов.

\title{
PROBLEMS OF THE OFFICER'S MANAGEMENT ACTIVITIES AND THE FORMATION OF ORGANIZATIONAL AND MANAGEMENT COMPETENCE IN THE MILITARY UNIVERSITY
}

\author{
S.G. Markovchin, S.A. Kravtsov
}

\begin{abstract}
Sergey G. Markovchin, Candidate of Technical Sciences, Head of the Novosibirsk Higher Military Command School, Novosibirsk, Russian Federation. E-mail:nvvku@mil.ru

Sergey A. Kravtsov, Lecturer, Department of Peacetime Divisions Management, Novosibirsk Higher Military Command School, Novosibirsk, Russian Federation. E-mail: kravtsov.79@mail.ru
\end{abstract}

\begin{abstract}
The article deals with the content, role and history of the development of management in the activities of officers of the Russian, Soviet and modern Russian army. The special role of pedagogical science in the formation of the theoretical foundations and skills of management activity is noted. The authors thoroughly analyzed, systematized, compared, compared and summarized many historical factors and aspects in the development of the Russian army concerning the issues of the officer's managerial activity, which made it possible to determine approaches to solving the problem of the formation of organizational and managerial competence in a military university of modern Russia. The tasks of the formation of competencies in the organizational and managerial activities of graduates of military universities, determined by the federal state educational standard for the specialty "Personnel Management", are analyzed, the essence of management and organization is determined in relation to the military organization. The definition of the essence of organizational and managerial competence of an officer is given, its structure and content are determined. The author analyzes the distinctive features of the process of forming organizational and managerial competence in a military university. It is noted that the basis of its formation is the training, education and development of cadets in the military pedagogical process. The study made it possible to define the content of the organizational and managerial competence of an officer of the Armed Forces of the Russian Federation, to reveal its essence and structure; identify and substantiate the position concerning the fact that the most important stage in the formation of an officer's organizational and managerial competence is the stage of his training at a military university.
\end{abstract}

Keywords: managerial activity, the formation of organizational and managerial competence of cadets.

Обоснование проблемы исследования. Управленческая деятельность офицера традиционно является определяющей в работе этого слоя кадровых военных. Сегодня эта проблема привлекает многих отечественных исследователей (И.И. Ихтисанов, А.В. Петкин, 
2016; С.В. Паньков, 2017; А.М. Пырский, А.В. Вертаев, 2017; Ю.Н. Коровин, 2018; А.С. Тимочкин, 2018; С.А. Богданов, О.А. Козлов, С.А. Воронов, 2019; А.В. Вертаев, 2019; П.И. Образцов, А.И. Козачок, А.И. Войцеховский, Р.Г. Пантелеев, 2019, др.).

Проблема управления в военном деле имеет глубокие исторические корни. В Артикуле воинском, разработанном при непосредственном участии Петра I, указывалось, что «начальнику принадлежит повелевать, а подчиненному послушну быть». ${ }^{1}$ Изначально управление осуществлялось чрезвычайно суровыми средствами, включая применение квалифицированной смертной казни, но уже к середине XIII века они были значительно очеловечены усилиями виднейших российских полководцев: П.А. Румянцева, Г.А. Потемкина, А.В. Суворова и их учеников. Вместе с тем, как указывают авторы Истории отечественной военной педагогики, «главным средством побуждения солдат выполнять одни и те же ненужные в бою действия служили мордобой и розги... за подразделениями и частями, шедшими на обучение, следовали повозки с розгами». ${ }^{2}$

Общие основы управления военнослужащими в условиях развивающегося капитализма и организации их воспитания как средства социального управления были сформированы М.И. Драгомировым [5]. Им возрождены идеи А.В. Суворова о гуманном отношении к солдату, обеспечении близости офицера и его подчиненных в жизни подразделения. В сложных условиях конца XIX - начала XX века они не были реализованы, в управлении войсками преобладал прусский административный подход, который сохранялся и в период Первой мировой войны.

В послереволюционный период управленческая деятельность командиров РККА приобретает выраженную классово-политическую направленность, в ней широко используются возможности воинских коллективов, структур партийных и комсомольских организаций и армейской общественности. Командиры получают в качестве организаторов политического воспитания «политруков», а в ходе обучения системно изучают практику воспитательной работы и педагогические основы управления войсками. ${ }^{3}$

В условиях Великой Отечественной войны значимость воспитания существенно возросла. По словам известного советского летчика А.И. Покрышкина, «наибольших успехов на фронте достигают те военные руководители, которые не только успешно организуют и управляют боевыми действиями, но и целенаправленно воспитывают своих подчиненных». ${ }^{4}$

При этом предельная ожесточенность и решительные цели войны предопределили суровость административно-правовых воздействий в управлении войсками и поведением населения страны и применении жестких мер авторитарной платоно-гербартианской педагогической практики (в войсках как превентивную воспитательную меру применяли «показательные» расстрелы паникеров, изменников, трусов; направление осужденных в штрафные части; лишение воинских званий и наград; действия заградительных подразделений; направление в места лишения свободы родственников изменников Родины, прекращение поддержки членов семей военнослужащих-дезертиров). ${ }^{5}$

В послевоенное время в целях повышения педагогического мастерства офицеров с 1946-1947 годов в программы обучения военных вузов вводится курс военной педагогики и психологии, предполагающий изучение основ управления личным составом и воспитания

\footnotetext{
${ }^{1}$ Титов Ю.П. Хрестоматия по истории государства и права России. М.: «Проспект», 1999. - С. 173 (472 с.).

2 Иванов В.Н., Лаптев Ю.В., Слепов В.Я. История отечественной военной педагогики: учебник. - СПб.: Военный институт ВВ МВД РФ, 1997. - С. 33 (219 с.).

${ }^{3}$ Партийно-политическая работа в Красной Армии: Документы. Июль 1929 г. - май 1941 г. - М.: Воениздат, 1985. - 535 c.

${ }^{4}$ Покрышкин А.И. Крылья истребителя. М.: Воениздат, 1948. - С. $36-54$ (140 с.).

5 Иванов В.Н., Лаптев Ю.В., Слепов В.Я. История отечественной военной педагогики: учебник. - СПб.: Военный институт ВВ МВД РФ, 1997. - С. 33 (219 с.).
} 
подчиненных. После смерти И.В. Сталина, с 1954 года в военных вузах было отменено преподавание педагогики и психологии. Это привело к преобладанию в обучении методов «натаскивания» и развитию военно-педагогической практики путем проб и ошибок (это было возвращением к позиции Л.Д. Троцкого, считавшего, что для подготовки войск и командиров педагогическая теория не нужна, а военное дело является не наукой, а ремеслом).

Возрождение военно-педагогической теории начинается с создания в 1959 году кафедры военной педагогики и психологии во главе с А.В. Барабанщиковым. Особенно эффективным оно было в 1970-1980 годы, когда были созданы полноценные основы военной дидактики и теории воспитания. Под его редакцией издана книга, сыгравшая значимую роль в развитии теории военной педагогики и психологии. ${ }^{6}$

В постсоветский период, к настоящему времени объем преподавания педагогики в ввузах критично уменьшился, что снижает их возможности в системном формировании организационно-управленческих качеств обучающихся. Федеральный государственный образовательный стандарт высшего образования по специальности «Управление персоналом» (Вооруженные Силы РФ, другие войска, воинские формирования и приравненные к ним органы Российской Федерации) (уровень специалитета) включает в область профессиональной деятельности выпускников: управление воинскими подразделениями, управление всесторонним обеспечением их деятельности; управление персоналом организации.

В качестве профессиональных закрепляются следующие организационные и управленческие задачи: организация повседневной деятельности подразделения, управление подразделениями в бою и повседневной деятельности; управление всесторонним обеспечением боя и повседневной деятельности; организация взаимодействия.

Федеральный государственный образовательный стандарт определяет необходимость формирования у выпускника военного вуза профессиональных компетенций в организационно-управленческой деятельности - $($ ПК-1) способность осуществлять планирование, организацию, руководство и контроль при управлении деятельностью подразделения... и (ПК-2) способность поддерживать постоянную боевую готовность подразделения и осуществлять его подготовку к бою. ${ }^{7}$

Теоретико-методологические основы исследования. Исследование проблемы управленческой деятельности офицера и формирование организационно-управленческой компетентности в военном вузе, было основано на научных трудах известных отечественных ученых, занимающихся вопросами военного дела (А.В. Барабанщиков, А.К. Быков, М.И. Драгомиров, В.Н. Иванов, Ю.В. Лаптев, А.Д. Лопуха, В.И. Лутовинов, В.Я. Слепов, др.). Исследование носило аналитический характер, поэтому в основном использовались методы социально-исторического и социально-педагогического анализа. Были подвергнуты анализу, систематизации, сравнению и обобщению многие исторические аспекты в развитии российской армии, касающиеся вопросов управленческой деятельности офицера, что позволило подойти к решению проблемы формирования организационно-управленческой компетентности у будущих офицеров в современном военном вузе.

Обсуждение результатов исследования. В современных условиях, когда противоборство широким спектром военных и невоенных средств ведется во всех средах и сферах социальной жизни общества, значение качества управления воинскими коллективами в гибридной войне существенно возрастает.

${ }^{6}$ Психология и педагогика высшей военной школы: учеб. пособие / под ред. А.В. Барабанщикова. - М.: Воениздат, 1989. - $366 \mathrm{c.}$

${ }^{7}$ Об утверждении ФГОС ВО по специальности «Управление персоналом»: Приказ МО и Н от 9.02.2016 г. № 97. - C. 4-12. 
Организационно-управленческая деятельность решает задачи управления в военной организации. Сущность организации в Толковом словаре русского языка представлена в нескольких смыслах: как организация чего-либо; как планомерное, продуманное устройство, внутренняя дисциплина; как объединение или государственное учреждение (организовать учредить, подготовить, наладить, объединить, упорядочить, устроить, сорганизовать...). ${ }^{8}$ Управление понимается здесь как направление движения организации.

В психологической науке управление часто представляет собой «комплекс необходимых мер влияния на группу, общество или людей с целью их упорядочения, сохранения качественной специфики, усовершенствования и развития» (А.П. Крысько, 2013). Сами процессы управления возникают в совместной деятельности людей, коллективов, социальных групп различного уровня. Управление, по мнению В.Г. Крысько, осуществляется во всех сложных динамических системах управления (социальных, психологических, биологических, технических, экономических, административных и др.) и основано на получении, обработке и передаче информации.

Поскольку объектом управления в ВС РФ являются люди, военные коллективы и социотехнические системы, управление носит социальный характер, являясь важнейшей функцией воинской социальной организации.

Как деятельность социального субъекта управление осуществляется воздействием на социальные ориентации и условия жизни объекта воздействия.

В отечественной социологии в качестве компонентов управления рассматриваются: управленческие воздействия, связанные с постановкой целей и формированием механизма целедостижения (фактически - организацией управления); самоорганизация; социальноорганизованный порядок, включающий социальные нормы, правила, образцы поведения, санкции, структуры и процедуры, ранее принятые управленческие решения. 9

В условиях воинской деятельности создаются специализированные организации, осуществляющие различные виды управленческой деятельности (экономической, административно-правовой, социальной, военного управления и др.).

Они должны по структуре и функциям соответствовать развитию социальной реальности. Управленческие воздействия должны согласовываться со свойствами внешней среды и реализовывать новые задачи не силовым давлением, а «благодаря правильной пространственно-временной организации (воздействие в нужное время в нужном месте)». ${ }^{10}$

При умелом сочетании административного управления и общественной самоорганизации (работа офицерских собраний, других структур армейской общественности), возможно отслеживание происходящих изменений в объекте управления, придание ему субъектности, мотивация развития позитивных тенденций, адаптация к реальному состоянию нормативного регулирования.

Вышесказанное представляет управление как сложный, многовекторный процесс, организатор которого должен иметь глубокие, разносторонние знания в области педагогики, психологии, социологии, конфликтологии и права.

Усложнение управленческих задач, решаемых в условиях ВС РФ как армии демократического общества, требует формирования адекватных теоретических основ формирования организационно-управленческой компетентности курсантов военного вуза и определения роли и места самовоспитания в решении этой задачи.

\footnotetext{
${ }^{8}$ Ожегов С.И., Шведова Н.Ю. Толковый словарь русского языка: 80000 слов и фразеологических выражений / РАН. 4-е изд. доп. - М.: ООО «ИТИ Технологии», 2006.- 944 с.

${ }^{9}$ Социологическая энциклопедия: в 2 т. Т. 2 // Руководитель научного проекта Г.Ю. Семигин. - М.: «Мысль», 2003. - 863 c.

${ }^{10}$ Там же.
} 
Организационно-управленческая компетентность есть индивидуальная, интегральная, динамично меняющаяся, относительно устойчивая характеристика личности офицера Вооруженных Сил Российской Федерации, результат его непрерывного профессиональноличностного развития, проявляющаяся в самостоятельном и ответственном решении задач обеспечения оптимальных взаимоотношений между военнослужащими, их объединениями, группами и коллективами, осуществляющими совместную деятельность в соответствие приказам, должностным обязанностям и нормам военно-профессиональной деятельности. Организационно-управленческая компетентность выступает фундаментальной личностной основой способности и готовности к поиску социально-значимых целей и способов решения усложняющихся задач организационно-управленческой деятельности офицера Вооруженных Сил Российской Федерации на любом этапе профессиональной карьеры. Организационноуправленческая компетентность - результат педагогического воздействия. Изначальные стимулы ее формирования создаются в условиях образовательного процесса военного вуза. Основными факторами ее развития выступают собственная активность курсанта военного вуза, мотивированные и целеустремленные накопление и самореализация им собственных потенциалов (способностей, знаний, умений, опыта, личных качеств), самоорганизация, интеграция освоенного и личного деятельностного опыта.

Анализируя работы, в которых раскрывается структура организационноуправленческой компетентности специалиста, мы пришли к выводу о том, что в разных авторских решениях есть общее начало - они «привязаны» к тому или иному пониманию компетентности (компетенции). Так, структура, предложенная Е.В. Савенковой, включает мотивационно-личностный (мотивационная ориентация), когнитивный (опыт, зафиксированный в знаниях), операционально-деятельностный (умения и владение способами деятельности в стандартных и нестандартных ситуациях) и коммуникативный компоненты. У О.В. Поповой структура каждой компетенции включает эмоциональномотивационный, когнитивный и поведенческий компоненты. Л.А. Попова объединяет в авторскую структуру мотивационные, интеллектуальные, личностные и поведенческие качества и дополняет их необходимыми знаниями и умениями.

Для определения структуры и содержания организационно-управленческой компетентности офицера Вооруженных Сил Российской Федерации мы воспользовались положениями И.А. Зимней, дополнив авторскую структуру компонентом, специально объединяющим профессионально важные качества личности, необходимые офицерууправленцу в особых условиях военной службы (Т.В. Данилова, Ю.А. Куис, И.И. Мельников, С.Д. Мухоед, О.П. Пузиков, И.А. Сидоров и др.). Авторские положения, сформированные в отношении различных компетенций организационно-управленческой деятельности офицеров (командные и инженерные должности в Сухопутных войсках, командные должности во внутренних войсках МВД, командные должности в МЧС), позволяют выделить общее, объединяющее эти явления знание. В итоге в структуре организационно-управленческой компетентности офицера Вооруженных Сил Российской Федерации нами выделены мотивационный, когнитивный, опытный, ценностно-смысловой, эмоционально-волевой и профессионально-личностный компоненты (рис. 1). 


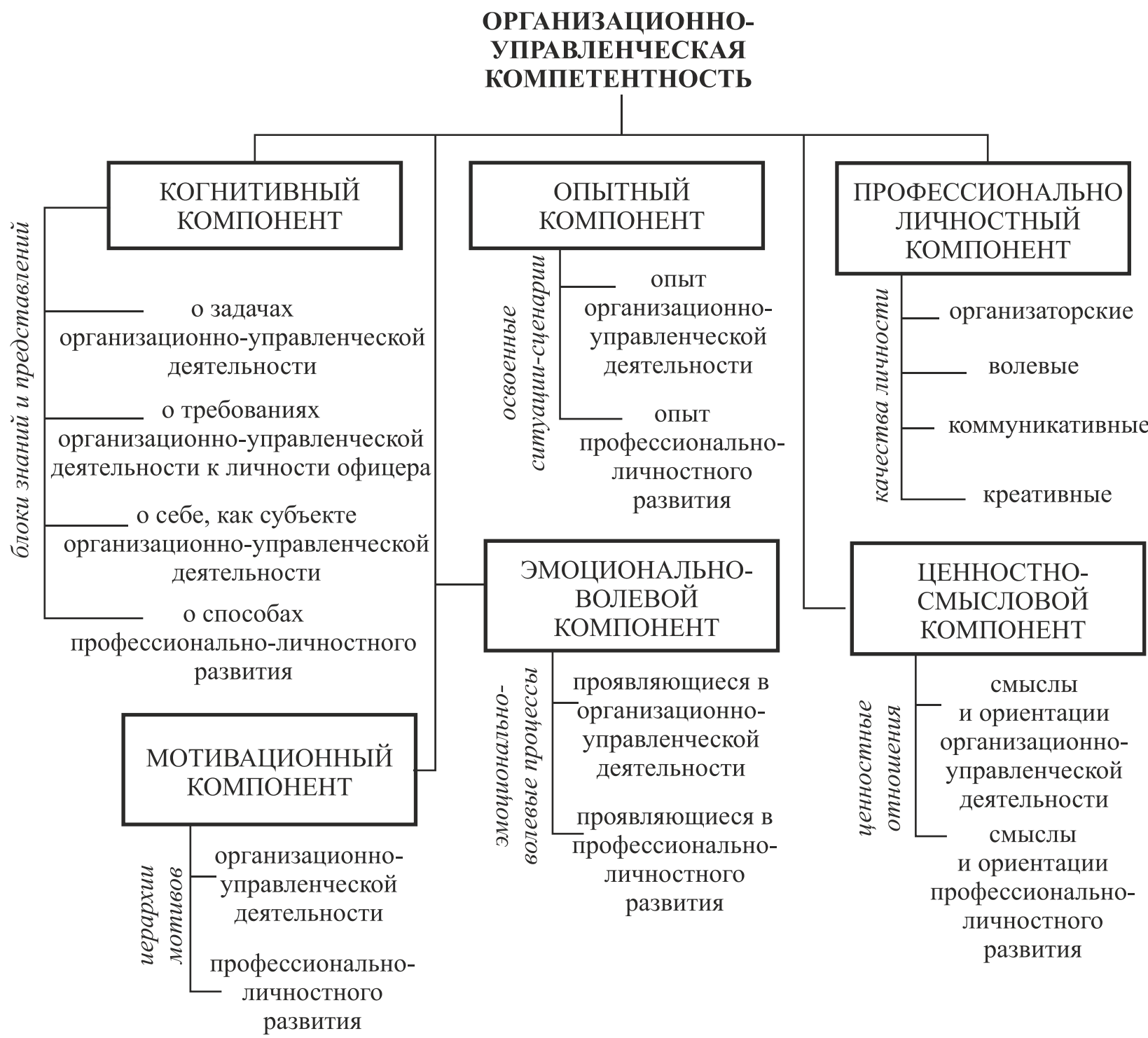

Рисунок 1. Структура организационно-управленческой компетентности офицера Вооруженных Сил Российской Федерации

Мотивационный компонент объединяет две актуализированные и устойчивые иерархии мотивов: мотивацию организационно-управленческой деятельности и мотивацию саморазвития в качестве управленца. В целом он определяет силу, устойчивость и характер внутренних динамических сил, побуждающих курсанта военного вуза к овладению организационно-управленческими компетенциями офицера. Одним из индикаторов такого уровня развития мотивационного компонента, на наш взгляд, может быть постоянная мотивация к организационно-управленческой деятельности и к развитию в качестве ее субъекта.

Когнитивный компонент предполагает в своем составе четыре группы знаний и представлений: о задачах организационно-управленческой деятельности вообще (основы управления, психологические и социальные вопросы управления) и в конкретной должности (состав, условия решения, методы и средства деятельности); об ее требованиях к личности офицера-управленца; о себе как потенциальном субъекте организационно-управленческой деятельности; о способах профессионально-личностного развития в качестве ее субъекта. В целом он формирует необходимую ориентировку офицера в пространстве организационно- 
управленческой деятельности. Основываясь на психологической концепции подготовки управленческих кадров Вооруженных Сил Российской Федерации, можно утверждать, что здесь уровень развития определяют преимущественно те знания, которые курсант военного вуза способен продуктивно использовать при освоении и реализации компетенций организационно-управленческой деятельности.

Опытный компонент предполагает объединение (интеграцию) интериоризированного опыта (усвоенные, осмысленные и эмоционально пережитые заимствованные ситуациисценарии действий), личного опыта организационно-управленческой деятельности, а также опыта профессионально-личностного развития. Он характеризует совокупность возможных задач организационно-управленческой деятельности курсанта военного вуза, для которых у него есть готовые ситуации-сценарии их решения. Предполагаем, что у субъекта организационно-управленческой деятельности есть два способа развития опытного компонента компетентности: собственная деятельность и интериоризация чужого опыта. Индикаторами развития компонента, на наш взгляд, могут стать и объем, и структура опыта.

Ценностно-смысловой компонент включает в себя ценности, на основе которых курсант военного вуза, создает для себя смыслы занятия организационно-управленческой деятельностью и развития в качестве ее субъекта, формирует соответствующие ценностные ориентации. Формирование организационно-управленческой компетентности предполагает связь смыслов управления с определенными ценностями. Так, в начале процесса формирования может быть сформировано ценностное отношение к своей подготовке (обучению, воспитанию, развитию), частью которой является освоение организационноуправленческих компетенций. На следующем уровне желательно ценностное отношение к самой организационно-управленческой компетентности как части профессионализма и условию самореализации в профессии. Наконец, на высшем уровне необходимо ценностное отношение к самой военно-профессиональной деятельности офицера, неотъемлемой частью которой является организационно-управленческая деятельность.

Эмоционально-волевой компонент объединяет внутренние, относительно устойчивые процессы регуляции организационно-управленческой деятельности и развития в качестве ее субъекта. Их также выделено две группы: эмоционально-волевые процессы, проявляющиеся в овладении и реализации управленческих компетенций и процессы, проявляющиеся в самостоятельном, активном профессионально-личностном развитии. В начале процесса формирования организационно-управленческой компетентности вполне достаточно критической самооценки, стремления курсанта военного вуза к преодолению трудностей с внешней поддержкой. В дальнейшем положительным индикатором развития станет самоорганизация и самоуправление формированием организационно-управленческой компетентности в соответствие требованиям, предъявляемым должностью. Наконец, на более высоком уровне развития предполагается наличие активного стремления к постоянному совершенствованию.

Профессионально-личностный компонент. Военные педагоги, исследующие проблему подготовки будущих офицеров к организационно-управленческой деятельности, неизменно выделяют значение личностных качеств в организационно-управленческой компетентности. (или близких по значению личностных образованиях). Вузовский уровень владения организационно-управленческими знаниями, умениями и навыками - важный, но не определяющий показатель компетентности, им на минимальном уровне обладает практически каждый выпускник военного вуза. Важнее в этом плане: «...организаторские способности, волевые качества (ответственность, целеустремленность, решительность, самостоятельность, выдержка, настойчивость, энергичность, инициативность), креативность, коммуникация и профессиональная мотивация». Профессионально-личностный компонент характеризует степень развития профессионально важных качеств курсанта военного вуза, 
критично важных для организационно-управленческой компетентности (организаторские, волевые, коммуникативные и креативные). Показателем успешности формирования компетентности в профессионально-личностном компоненте может стать их проявление в организационно-управленческой деятельности.

Процесс формирования организационно-управленческой компетентности реализуется на основе концепции профессионально-личностного развития (Н.В. Кузьминой, А.К. Марковой, Л.М. Митиной, Э.Ф. Зеера, др.).

Первой отличительной чертой процесса формирования организационноуправленческой компетентности офицера является активная позиция, твердая ориентировка личности на саморазвитие, именно это обстоятельство отличает модель профессионального развития от модели профессиональной адаптации.

Вторая отличительная черта - не просто исполнение организационно-управленческой деятельности, а ее внутреннее переживание и осмысление, рефлексия.

Наконец, третьей отличительной чертой процесса формирования организационноуправленческой компетентности офицера Вооруженных Сил Российской Федерации, в русле концепции профессионально-личностного развития, является самоопределяющаяся личность обучающегося, его цели, жизненные планы, идеалы, личностные и физические свойства, возможности, склонности, чего от него ждут коллектив, общество.

Формирование организационно-управленческой компетентности - это процесс творческого, критичного и рефлексивного использования курсантом знаний, умений и опыта, получаемых в военном вузе при овладении организационно-управленческими компетенциями. Основой формирования организационно-управленческой компетентности курсанта военного вуза выступает его обучение и воспитание, значимым фактором формирования - самовоспитание, соответствующее сущностным признакам процесса формирования организационно-управленческой компетентности.

Личностная составляющая организационно-управленческой деятельности формируется в процессе развития образующих ее личностных качеств. Можно предположить, что в развитии организационно-управленческой компетентности курсантов следует прежде всего обратить внимание на составляющие образовательного процесса военного вуза, активизирующие сложные и комплексные процессы развития личности, в том числе на самовоспитание, психолого-педагогическая поддержка которого в интересах развития организационно-управленческой компетентности курсанта остается пока еще нерешенной научной задачей.

Заключение и выводы. Результаты проведенного исследования позволяют говорить о том, что уровень развития организационно-управленческой компетентности будущего офицера Вооруженных Сил Российской Федерации определяется в деятельности по освоению и реализации организационно-управленческих задач в соответствие специальности и должностному предназначению. Для этапа обучения в военном вузе, где предполагается психолого-педагогическая поддержка процесса формирования организационноуправленческой компетентности курсантов военного вуза, необходима некоторая дифференциация результата самовоспитания. Для педагогического управления процессом формирования организационно-управленческой компетентности курсантов военного вуза стандартами, квалификационными требованиями конкретной специальности и основными положениями в области профессионального воспитания (интегрированы в основную профессиональную образовательную программу военного вуза) определяется уникальный набор организационно-управленческих компетенций. По сути - это усредненные и обезличенные внешне заданные требования, основанные на лучших образцах выполнения типовых организационно-управленческих задач (сложившееся в профессиональном опыте понимание профессионализма в организационно-управленческой деятельности) в 
должности, на которую предназначен выпускник. Вместе с тем относительно этих образцов вполне возможно дать общую характеристику уровням формирования организационноуправленческой компетентности курсантов военного вуза, которые позволяли бы дать объективную оценку ее состояния.

Таким образом, все вышеизложенное позволило:

- дать определение содержанию организационно-управленческой компетентности офицера Вооруженных Сил Российской Федерации, раскрыть его сущность и структуру.

- выявить и обосновать, что важнейшим этапом формирования организационноуправленческой компетентности офицера является этап его обучения в военном вузе. Вместе с тем, основной процесс - это самовоспитание личности, отвечающее принципам профессионально-личностного развития: активности, самостоятельности и сознательности личности российского офицера.

\section{Литература:}

1. Богомолов А.Н. Показатели педагогической готовности выпускников вузов войск национальной гвардии Российской Федерации // ЦИТИСЭ. - 2020. - № 1 (23). - С. 206215. DOI: http://doi.org/10.15350/24097616.2020.1.19

2. Богданов С.А., Козлов О.А., Воронов С.А. Управленческая деятельность офицера Росгвардии (сущность и содержание) // Профессиональное образование в России и за рубежом. - 2019. - № 4(36). - C. 81-87. URL: https://www.elibrary.ru/item.asp?id=42362639

3. Вертаев А.В. Использование метода служебно-боевых ситуаций для формирования управленческих компетенций у курсантов вузов войск национальной гвардии российской федерации // Общество: социология, психология, педагогика. - 2019. - № 4(60). C. 114-117. DOI: $10.24158 / \mathrm{spp} .2019 .4 .20$

4. Денников Е.И., Боровицкий А.М. Формирование организационнопрогностических компетенций у будущих офицеров Росгвардии в жизнедеятельности воинского коллектива // Молодой ученый. - 2020. - № 5. - (295). - С. 308-310.

5. Драгомиров М.И. Избранные труды. Вопросы воспитания и обучения войск / Под ред. д.и.н., профессора Л. Г. Бескровного. - М.: Военное издательство Министерства обороны СССР, 1956. - 686 с.

6. Ихтисанов И.И., Петкин А.В. Готовность курсантов военных институтов к управленческой деятельности // Ученые записки университета им. П.Ф. Лесгафта. - 2016. №7 (137). - C. 27-30. URL: https://www.elibrary.ru/item.asp?id=26482049

7. Жумаханов А.З. Подготовка курсантов к формированию социальнопрофессионального опыта в процессе войсковых практик // Вестник Омского государственного педагогического университета. Гуманитарные исследования. - 2019. - № 2(23). - № 109-112. URL: https://www.elibrary.ru/item.asp?id=39210202

8. Карчакин А.Н. Особенности социализации личности в условиях военнопрофессиональной среды // Мир науки, культуры и образования. - 2020. - № 2(81). - С. 240242. DOI: $10.24411 / 1991-5497-2020-00277$

9. Коровин Ю.Н. Теоретические подходы к организации управленческой деятельности офицера войск национальной гвардии Российской Федерации в системе военного управления // Современная наука: актуальные проблемы теории и практики. - 2018. - № 5. - C. 29-33. URL: https://www.elibrary.ru/item.asp?id=35436680

10. Коровин Ю.Н. Особенности управленческой деятельности офицеров войск национальной гвардии Российской Федерации // Научное мнение. - 2018. - № 5. - С. 36-41. URL: https://elibrary.ru/item.asp?id=35000937 
11. Куршев А.В. Гражданское воспитание будущих офицеров в процессе модернизации военного образования: монография. - Казань: Казанский научноисследовательский технологический университет (КНИТУ), 2017. - 136 с. ISBN: 978-57882-2369-8

12. Образцов П.И., Козачок А.И., Войцеховский А.И., Пантелеев Р.Г. Критериально-оценочный аппарат сформированности организационно-управленческой компетенции будущего военного специалиста / Р.Г. Пантелеев и др. // Вестник воронежского государственного университета. - 2019. - № 1 - C. 73-77. URL: https://elibrary.ru/item.asp?id=37278582

13. Козачок А.И., Пантелеев Р.Г., Модель процесса формирования организационно-управленческой компетенции будущих военных специалистов // Инновации в образовании. - 2019 - № 2. - C. 34 45. URL: https://elibrary.ru/item.asp?id=36897142

14. Коровин Ю.Н. Теоретические подходы к организации управленческой деятельности офицера войск национальной гвардии Российской Федерации в системе военного управления // Современная наука: актуальные проблемы теории и практики. 2018. - № 5. - C. 29-33. URL: https://elibrary.ru/item.asp?id=35436680

15. Паньков С.В. Тенденция развития подготовки офицеров к управленческой деятельности в современных условиях // Вестник Омского государственного педагогического университета. - 2017. - № 1(14). - C. 95-98. URL: https://elibrary.ru/item.asp?id=29232208

16. Плотников Е.Г., Дашкин В.М. Технология реализации модели формирования готовности будущего офицера войск национальной гвардии к педагогическому взаимодействию с подчинёнными // Мир науки, культуры и образования. - 2019. - № 5(78). C. 257-259. DOI: 10.24411/1991-5497-2019-00105

17. Пырский А.М., Вертаев А.В. Оценка уровня сформированности профессионально-управленческих качеств курсантов вузов Федеральной службы войск Национальной гвардии Российской Федерации // Общество: социология, психология, педагогика. - 2017. - № 6. - С. 46-51. DOI: 10.24158/spp.2017.6.8

18. Сергиенко А.И. Педагогические условия морально-психологической подготовки курсантов в образовательном процессе военного вуза // Вестник КГУ. Т. 25. 2019. - № 2. - C. 141-146. DOI:10.34216/2073-1426-2019-25-2-141-146

19. Тимочкин А.С. Проблемы формирования управленческих компетенций у младших специалистов войск национальных гвардии РФ // Мир науки, культуры, образования. - 2018. - № 4(71). - C. 242-243. URL: https://elibrary.ru/item.asp?id=35436680

20. Утюганов А.А. Система ценностно-смысловых ориентаций курсантов вузов национальной гвардии: феноменология и психолого-педагогические детерминанты формирования. Диссертация на соиск. уч. ст. док. псих. наук: 19.00.07 - педагогическая психология. - Кемерово: КГУ, 2019. - 401 с.

21. Успаленко В.Б., Плотникова Е.Г. Структура организационно-управленческой деятельности военного специалиста в области применения информационных технологий // Концепт. - научно-методический электронный журнал. - 2018. - № 6. - С. 66-77. DOI: 10.24422/MCITO.2018.6.14498

22. Холина Л.И., Серёдкин Н.А. Профессиональная подготовка курсантов военного вуза к управленческой деятельности в процессе решения тактических задач // Профессиональное образование в современном мире. - 2016. - № 6(2). - С. 268-274. DOI: $10.15372 / P E M W 20160211$

\section{References:}


1. Bogomolov A.N. Indicators of pedagogical readiness of graduates of universities of the troops of the National Guard of the Russian Federation. CITISE, 2020, no. 1 (23), pp. 206-215. (In Russian) DOI: http://doi.org/10.15350/24097616.2020.1.19

2. Bogdanov S.A., Kozlov O.A., Voronov S.A. Management activity of the officer of the Russian Guard (essence and content). Professional education in Russia and abroad, 2019, no. 4 (36), pp. 81-87. (In Russian) URL: https://www.elibrary.ru/item.asp?id=42362639

3. Vertaev A.V. The use of the method of service-combat situations for the formation of managerial competencies among cadets of universities of the National Guard troops of the Russian Federation. Society: sociology, psychology, pedagogy, 2019, no. 4 (60), pp. 114-117. DOI: 10.24158/spp.2019.4.20

4. Dennikov E.I., Borovitsky A.M. Formation of organizational and prognostic competencies among future officers of the Russian Guard in the life of a military collective. Young Scientist, 2020, no. 5 (295), pp. 308-310. (In Russian)

5. Dragomirov M.I. Selected Works. Issues of education and training of troops. Moscow, Ministry of Defense of the USSR Publ., 1956, 686 p. (In Russian)

6. Ikhtisanov I.I., Petkin A.V. Readiness of cadets of military institutes for management activities. Uchenye zapiski universitet im. P.F. Lesgaft, 2016, no. 7 (137), pp. 27-30. (In Russian) URL: https://www.elibrary.ru/item.asp?id=26482049

7. Zhumakhanov A.Z. Training cadets for the formation of social and professional experience in the process of military practice. Bulletin of the Omsk State Pedagogical University. Humanities research, 2019, no. 2 (23), pp. 109-112. (In Russian) URL: https://www.elibrary.ru/item.asp?id=39210202

8. Karchakin A.N. Features of socialization of the individual in the militaryprofessional environment. World of Science, Culture and Education, 2020, no. 2 (81), pp. 240-242. (In Russian) DOI: 10.24411/1991-5497-2020-00277

9. Korovin Yu.N. Theoretical approaches to the organization of administrative activities of an officer of the National Guard of the Russian Federation in the system of military control. Modern science: actual problems of theory and practice, 2018, no. 5, pp. 29-33. (In Russian) URL: https://www.elibrary.ru/item.asp?id=35436680

10. Korovin Yu.N. Features of the management activities of officers of the National Guard of the Russian Federation. Scientific opinion, 2018, no. 5, pp. 36-41. (In Russian) URL: https://elibrary.ru/item.asp?id=35000937

11. Kurshev A.V. Civil education of future officers in the process of modernization of military education. Monograph. Kazan: Kazan Scientific Research Technological University Publ., 2017, 136 p. ISBN: 978-5-7882-2369-8

12. Obraztsov P.I., Kozachok A.I., Voitsekhovsky A.I., Panteleev R.G. The criterionevaluative apparatus of the formation of the organizational and managerial competence of the future military specialist. Bulletin of the Voronezh State University, 2019, no. 1, pp. 73-77. (In Russian) URL: https://elibrary.ru/item.asp?id=37278582

13. Kozachok AI, Panteleev RG, Model of the process of forming the organizational and managerial competence of future military specialists. Innovations in education, 2019, no. 2, pp. 34 45. (In Russian) URL: https://elibrary.ru/item.asp?id=36897142

14. Korovin Yu.N. Theoretical approaches to the organization of administrative activities of an officer of the National Guard of the Russian Federation in the system of military control. Modern science: actual problems of theory and practice, 2018, no. 5, pp. 29-33. (In Russian) URL: https://elibrary.ru/item.asp?id=35436680

15. Pankov S.V. The development trend of training officers for management activities in modern conditions. Bulletin of the Omsk State Pedagogical University, 2017, no. 1 (14), pp. 95-98. (In Russian) URL: https://elibrary.ru/item.asp?id=29232208 
16. Plotnikov E.G., Dashkin V.M. Technology of implementation of the model of formation of the readiness of the future officer of the National Guard troops for pedagogical interaction with subordinates. World of Science, Culture and Education, 2019. no. 5 (78). pp. 257259. (In Russian) DOI: 10.24411/1991-5497-2019-00105

17. Pyrsky A.M., Vertaev A.V. Assessment of the level of formation of professional and managerial qualities of cadets of universities of the Federal Service of the National Guard of the Russian Federation. Society: sociology, psychology, pedagogy, 2017, no. 6, pp. 46-51. (In Russian) DOI: $\underline{10.24158 / \mathrm{spp} .2017 .6 .8}$

18. Sergienko A.I. Pedagogical conditions of moral and psychological training of cadets in the educational process of a military university. Bulletin of $K S U, 2019$, vol. 25, no. 2, pp. 141146. (In Russian) DOI:10.34216/2073-1426-2019-25-2-141-146

19. Timochkin A.S. Problems of the formation of managerial competencies among junior specialists of the Russian National Guard troops. World of Science, Culture, Education, 2018, no, 4 (71), pp. 242-243. (In Russian) URL: https://elibrary.ru/item.asp?id=35436680

20. Utyuganov A.A. The system of value-semantic orientations of cadets of the National Guard universities: phenomenology and psychological and pedagogical determinants of formation. Kemerovo, KSU Publ., 2019, 401 p.

21. Uspalenko V.B., Plotnikova E.G. The structure of the organizational and managerial activity of a military specialist in the field of application of information technologies. Concept scientific and methodological electronic journal, 2018, no. 6, pp. 66-77. (In Russian) DOI: 10.24422/MCITO.2018.6.14498

22. Kholina L.I., Seryodkin N.A. Professional training of cadets of a military university for management activities in the process of solving tactical problems. Professional education in the modern world, 2016, no. 6 (2), pp. 268-274. (In Russian) DOI: 10.15372/PEMW20160211 